Affective Factors and Fluent Performance: French Learners' Appraisals of L2 Speech Tasks

\author{
Judit Kormos \\ Lancaster University \\ Yvonne Préfontaine \\ Oracle Corporation
}

\begin{abstract}
Author Note
Correspondence concerning this article should be addressed to
\end{abstract}

Judit Kormos, Department of Linguistics and English Language, Lancaster University, Lancaster, County South, LA1 4YL, United Kingdom

E-mail: j.kormos@lancaster.ac.uk 


\title{
Affective factors influencing fluent performance: French learners' appraisals of second language speech tasks
}

\begin{abstract}
The present mixed-methods study examined the role of learner appraisals of speech tasks in L2 French on the fluency of their speech as well as expert rater's perceptions of their fluency. Forty adult learners in a Canadian immersion programme participated in the study which compared four sources of data: (1) participants' performances of three narrative tasks differing in their conceptualization and formulation demands, (2) a questionnaire on their interest, task-related anxiety, task motivation, and perceived success in task-completion, (3) an interview in which they elaborated on their perceptions of the tasks, and (4) ratings of their performances by three native speakers. Findings showed the cognitive demands of tasks were associated with learners' affective responses to tasks as well as objective and subjective measures of performance. Furthermore, task-related anxiety and perceived success in task completion were the most important affective factors associated with fluent task performance, whereas interest and task motivation were correlated with native speakers' fluency ratings. These results are discussed in terms of how task design and implementation can contribute to enhanced task motivation and performance in the classroom.
\end{abstract}

\section{Introduction}

Narrative speech tasks are routinely used in classroom language learning contexts to further language development and to assess second language (L2) speech production. However, the issue of how tasks relate to learners' affective response and performance in the classroom has received relatively little attention. On the one hand, affective characteristics might influence learners' attitudes and interest in tasks, impact the fluency of their performance, and ultimately affect how they learn on tasks. On the other hand, various characteristics of tasks and their design features elicit different affective responses from language learners. These affective responses might either enhance or limit engagement and subsequent L2 development. A better understanding of the relationship between task demands, affective factors and performance might provide teachers and course designers with a more informed basis for selecting and designing tasks for L2 learning and assessment.

\section{Affective factors in task performance}

Affective characteristics, such as attitudes, motivation and anxiety play an important role in language learning processes (Dörnyei \& Ryan, 2015). Yet if one wants to understand how students learn by engaging in tasks, it is also important to consider task-specific affective factors such as task-motivation, situational interest and anxiety related to oral performance. One such task-specific factor is task-motivation. This concept was first introduced to the field of SLA by Jülkunen (1989). Similar to Boekaerts' (2002) conceptualization, Jülkunen (1989) defined task motivation as a conglomerate of trait motivation, or learners' general motivational dispositions, and state motivation, meaning how motivated learners perform in a given task. Students appraise tasks by considering their abilities in performing them, the pleasure they derive in completing them, and their impression of the value of the task (Boekaerts, 2002). An additional element of task motivation is the cost of performing the task, which in educational psychology, is often described in terms of the level of anxiety students might experience while carrying out the task (Boekaerts, 2002). In the field of general educational psychology, cognitive and affective task appraisals have been found to predict task engagement and 
subsequent learning outcomes (see e.g., Harackiewicz, Durik, Barron, Linnenbrink, \& Tauer, 2008).

In second language acquisition (SLA) research, Dörnyei (2002) argued that task motivation might not simply be a composite of relatively stable trait and state task-related motivation but also a dynamic process, which he called motivational task processing. With the help of this task processing system, L2 learners appraise the given learning task, execute it, and apply action control processes that help them regulate their performance. Dörnyei and Kormos (2000) found that L2 learners' attitudes about the task as well as their general attitudes toward the language course were significantly correlated with the number of words and turns produced in a dialogic oral argumentative task. They also examined the relationship between task motivation and the quality of students' output in a later study (Dörnyei \& Kormos, 2004) and their results revealed weak associations between qualitative output measures and motivational variables. The results, however, suggested that task-related attitudes were highly correlated with the number of counter-arguments the learners produced in the argumentation task, which they considered an important measure of task engagement.

In a recent study, Poupore (2013) examined the dynamic interplay of various taskrelated and motivational variables. His findings suggested that different factors accounted for increased motivational processing in different types of L2 learning tasks. In some tasks, motivational effort, reported before and after the completion of the task, and task relevance played an important role, whereas in others, it was learners' emotional state that influenced task-related attitudes. The results of the study also revealed that the cognitive complexity of the task and the nature of the topic were important factors contributing to the motivational value of tasks. High cognitive demands and abstract content tended to result in less favourable task-related attitudes.

Interest is another concept closely related to task-motivation, and it also has a state and situation-specific dimension (Hidi, Renninger, \& Krapp, 1992). Situational interest arises as an affective response to the environment, which includes tasks and their content, whereas individual interest is a state-like characteristic that predicts whether someone would re-engage with a particular task (Hidi \& Renninger, 2006). Situational interest can be increased by the structural characteristics, novelty, content and personal relevance of tasks and can be generated by teachers or the learners themselves (Renninger, Nieswandt, \& Hidi, 2015). In the academic domain, Hidi and Renninger (2006) have found that individual interest in an interaction with situation-specific interest positively contribute to motivation, learning outcomes and achievement. In SLA research, Poupore's (2015) results suggest that L2 learners consider tasks with content relating to personal life themes and life challenges more interesting and intrinsically motivating than tasks covering abstract topics that have little personal relevance for them (see also Lambert, Philp \& Nakao in current issue).

Another construct which is interrelated with task-motivation and engagement is anxiety, which can be both a general personality trait or arise in response to a particular situation (Spielberger, 1983). Oral communication in another language can be particularly anxiety-provoking, which has resulted in the conceptualization of the speaking-related subconstruct of foreign language anxiety (FLA): communication apprehension (Horwitz, Horwitz, \& Cope, 1986). MacIntyre and Gardner (1994) argued that anxiety affects L2 learning processes at three stages: processing input, carrying out the cognitive operations involved in turning input into knowledge representations, and producing L2 output. Their results indicated that judgements of L2 fluency, syntactic complexity and accentedness were moderately or strongly related to input, processing and output anxiety measures. Robinson and Gilabert's (2007) research also revealed that anxiety and the characteristics of spoken tasks interact and might jointly influence the efficiency of speech production. 
The present study examines four task-specific affective factors: task-related motivation, anxiety, interest and self-evaluation of success. This choice was motivated by the fact that these factors can be pedagogically manipulated by task-design and classroom implementation features and can have a potential influence on how learners engage and perform in particular instructional tasks.

\section{Task-related variation in the fluency of performance}

As fluency is particularly sensitive to task characteristics and design features (cf. Jackson \& Suethanapornkul, 2013 meta-analysis) and is an important indicator of spoken language abilities (Segalowitz, 2010), we decided to focus on this aspect of learners' task performance. The concept of fluency encompasses both objective acoustic and temporal measures of speech production and subjective perceptions of fluency. According to Segalowitz (2010, p. 48), utterance fluency designates the temporal variables of speech or the "oral features of utterances that reflect the operation of underlying cognitive processes", while perceived fluency refers to the "inferences listeners make about a speaker's cognitive fluency based on their perception of utterance fluency".

Empirical findings about how task characteristics impact on L2 fluency are often contradictory. These results are partly due to differing operationalizations of fluency. In most task-based studies, fluency was conceptualized in line with Lennon's (2000) definition as "rapid, smooth, accurate, lucid, and efficient translation of thought or communicative intention under the temporal constraints of on-line processing" (p. 26). Despite the shared conceptual framework, there is a large variation in how fluency is actually measured. In task-based studies, utterance fluency is often assessed as: breakdown fluency, which relates to pausing behavior, repair fluency, which is measured by the frequency of repetitions and self-corrections, and speed fluency, which reflects the speed with which speech is delivered (for a recent discussion, see Bosker, Pinget, Quené, Sanders, \& De Jong, 2013; De Jong, Steinel, Florijn, Schoonen, \& Hulstijn, 2012).

Recent studies by Kormos and Trebits (2012) and Préfontaine and Kormos (2015) have shown a complex interaction between task characteristics and how learners allocate their attentional resources in task performance. This interaction is manifest in varying levels of fluency and quality of linguistic output. The research reported in this paper extends this line of research by investigating the inter-relationships of task demands, affective appraisals of tasks and the fluency of L2 performance.

Based on the aforementioned conceptualizations of L2 fluency and affective factors influencing L2 performance, the present study addresses the following research questions:

1. How do L2 French speakers' affective appraisals differ with respect to three tasks that vary in the cognitive demands they place on the conceptualization and formulation phases of speech production?

2. How are learners' affective appraisals of speech tasks related to utterance fluency?

3. How are learners' affective appraisals of speech tasks related to perceived fluency?

\section{Method}

In the present study, we employed a mixed-methods research design to account for the complexity of the aforementioned fluency and affective constructs analyzed. We applied repeated analysis of variance for establishing task-related differences and correlational analyses for investigating the relationships between affective task appraisals and fluency phenomena. 


\section{Participants}

Forty first language L1 English volunteer participants (21 females and 19 males) between 18 to 69 years old $(M=26$ years, $S D=10.57)$ rendered speech performances in French based upon three monologic tasks. According to the university's online multiple-choice placement test, which assessed grammar, vocabulary, listening, speaking and writing skills, the participants were elementary, intermediate and advanced proficiency. The participants were studying in a five-week French immersion program in a francophone university environment in the province of Québec. Participants were recruited by advertisement and were paid for their participation. The sample population consisted of 26 Canadians, 13 Americans and one British student. Thirty participants had had approximately six years of classroom-based French language learning, while the remaining ten had had an average of nine years in a French immersion setting in Canada. The total sample represented students from each of the proficiency groups as determined by the university.

In order to answer our third research question relating to perceived fluency, three native speaker raters were recruited to judge the fluency L2 speech production. All three raters were L2 French language instructors from the university, and although they had many years of teaching experience between them, none had previously been involved in an L2 fluency or speech rating research project. Furthermore, they were not formally trained phoneticians or responsible for teaching French phonetics.

\section{Materials}

The study employed three monologic narrative tasks. The unrelated picture narration task (Task 1) required participants to invent a story based on six unrelated pictures and then narrate this story. The story retell (Task 2) required participants to read a short story in English about a horseback riding accident and then paraphrase it in French. The participants were informed that the skill being assessed was not that of translation, but rather their ability to retell a story as though they were speaking to a friend. Finally, the related picture narration task (Task 3 ), required participants to narrate a story based on a sequential 11-frame cartoon strip. For all three tasks, students had access to the pictures and text during the narration. The design of the three tasks thus varied in whether participants had to invent a storyline (+/- storyline) and in the mode of the input for the task (visual vs. verbal). Accordingly, the tasks placed different cognitive demands on the participants. Task 1 was taxing in terms of conceptualization demands (students creatively constructed the content of the narrative) as well as formulating the ideas in the L2 (c.f. Kormos, 2011; Levelt, 1989). In contrast, Tasks 2 and 3 were taxing primarily in terms of the encoding/linguistic formation phase of speech production (participants were provided with the task content visually or verbally, but had to use their linguistic resources for narrating the stories).

An L2 Fluency Assessment Grid (see Appendix 1) was used to indicate native speaker raters' general assessment of the participants' French fluency. This grid consisted of six descriptors, in the form of "can do" statements, from the Council of Europe's (2001) Common European Framework (CEF) (Table 3, pp. 28-29).

A Task Appraisal Questionnaire (see Appendix 2) was administered in English to assess the participants' affective responses to the three speaking tasks. The questionnaire was adapted from Robinson's (2001) five-item scale and included items about perceptions of task anxiety, success in task completion, interest in task completion, and motivation to complete more tasks like these. These questions aimed to assess four important affective aspects of task appraisals as discussed in the literature review above: task-related motivation, anxiety, interest and selfevaluation of success. 


\section{Procedure}

Prior to the data collection, participants completed a brief background questionnaire. The performance data for the study were then collected in a face-to-face meeting with the researcher. Participants responded to three different narrative speech prompts after threeminute planning. Students' responses ranged from one to four minutes. The tasks were administered in a counter-balanced design to control for task order effects. After each task performance, participants completed the Task Appraisal Questionnaire (Appendix 2), followed by the retrospective interviews in which students were given the opportunity to provide qualitative feedback about the task characteristics they believed influenced or hindered their fluent speech production.

The retrospective interview technique was used to collect data about how participants appraised the three tasks relative to task-related motivation, anxiety, interest and selfevaluation of success. The interviews were conducted using the method proposed by Ericsson and Simon (1980, 1993). This technique enabled the participants to have an active role in verbalizing their personal experience concerning how affective characteristics embedded in tasks influenced their overall L2 speech performance by responding to open-ended questions (e.g., which task provoked feelings of anxiety, and why, which task did you find most interesting, and why). In total, 120 complete observations were obtained using the retrospective method. As the tasks were administered in a counter-balanced design, any potential effects of the interview and the questionnaire on performance are distributed equally across conditions.

All participants' contributions were anonymous for the raters. The speech performances were provided to the raters in a randomized counter-balanced format to ensure they could not rate the same student equally across all three tasks. The entire rating project was performed online. The three raters listened to each of the 120 speech performances and allocated a score using the grid after listening to each of the three speech performances. Ranging from the lowest level (A1) to the highest (C2), the raters selected one descriptor to represent their assessment of oral performance in French. These evaluations were then converted into a six-point numerical scale. The raters were not trained to use the rating instrument. The rationale behind this decision was to avoid influencing ratings by a pre-defined conceptualization of fluency and to avoid imposing a self-fulfilling construct of L2 fluency.

\section{Analyses}

Affective task appraisals were measured both quantitatively and qualitatively in the following two ways. First, the participants rated each of the three task performances by means of the Task Appraisal Questionnaire (see Appendix 2). For the analysis, the responses were computed on a scale ranging from one to six, where one represented the least extreme response and six the highest on each of the four variables (nervousness, success, interest and task motivation). Second, the participants' retrospective interview comments were analyzed to identify the main task characteristics that they considered as either enabling or disenabling fluent performance. Following Rubin and Rubin's (2005) guidelines, we first extrapolated concepts that represented important ideas, then synthesized and consolidated the different concepts, created codes to designate these concepts and grouped all data by codes. Finally, we searched for patterns and comparisons between themes.

In task-based studies, utterance fluency is often measured as: breakdown fluency, which is related to pausing behavior, repair fluency, which is operationalized as the frequency of repetitions and self-corrections, and speed fluency, which expresses the speed with which speech is delivered (for a recent discussion, see Bosker et al., 2013; De Jong et al., 2012). In our study we operationalized utterance fluency in line with the recent work of De Jong et al., (2012). They suggest the use of pause frequency and pause length as accurate measures of breakdown fluency. For the assessment of speed fluency they recommend the assessment of 
articulation rate, that is, the number of syllables divided by speaking time. We did not conduct an analysis of repair fluency in our study because the frequency of self-repairs might also reflect learners' attention to the accuracy of their output (Gilabert, 2007; Kormos, 2000).

To analyze utterance fluency, the L2 speech performances were automatically evaluated using Pratt, a speech analysis software program designed by Boersma and Weenink (2010), and software script by De Jong and Wempe (2009), which we modified for the purposes of our study. Based on previous L2 fluency research (Ejzenberg, 2000; Freed, 2000; Freed, Segalowitz, \& Dewey, 2004; Kormos \& Dénes, 2004; Lennon, 1990; Riggenbach, 1991; Towell, Hawkins, \& Bazergui, 1996), the utterance fluency variables were operationalized as follows:

1. Articulation rate (AR): The total number of syllables divided by the total phonation time (excluding pauses) expressed in seconds. Following Riggenbach (1991), the articulation rate was unpruned with all partial words and asides counted. Praat was configured to detect pauses of 0.25 seconds and above.

2. Pause Frequency (PF): The total number of pauses divided by the total duration in seconds of the speech sample. Only pauses of 0.25 seconds and above will be used in the calculations.

3. Average pause time (APT): The average pause time was calculated by dividing the total duration of all pauses by the number of pauses in a given speech sample.

We applied repeated analysis of variance for establishing task-related differences and correlational analyses for investigating the relationships between affective task appraisals and fluency phenomena. Using the guidelines established by Cohen (1988), the correlation cut-off points were set as follows: $r=.10$ to .29 (small), $r=.30$ to .49 (medium), and $r=$ .50 to 1.0 (large).

\section{Results}

\section{Quantitative analysis}

First we calculated descriptive statistics for participants' task appraisals (see Table 1) and the normal distribution of the data was checked. To facilitate comprehension, Task 1 refers to the unrelated picture narration, Task 2 to the written story retell, and Task 3 to the comic strip narration. Task 3 prompted the lowest means for perceived anxiety and the highest values for perceived success. Conversely, Task 1 prompted the highest means for perceived anxiety and lowest means for perceived success. Task 2 in contrast prompted the highest means for interest and motivation.

\section{Insert Table 1 here}

In order to answer our first research question concerning how French L2 learners' affective appraisals of narrative speech tasks differed, we conducted a series of one-way within-subject ANOVAs and subsequent paired $t$-test comparisons. Even though the questionnaire yielded ordinal data, parametric analyses were used because our data was normally distributed. ANOVA analyses are relatively insensitive to violations of equidistance if assumptions of normality are met (Lantz, 2013). The ANOVAs showed a significant effect for two of the four variables, namely: anxiety $[F(2,38)=3.56, p<.05$, multivariate eta squared $=0.16]$; and success $[F(2,38)=5.02, p<.05$, multivariate eta squared=0.21]. Following Cohen (1988), these effect sizes can be considered large. Next, we applied $t$-tests to establish which tasks differed from each other for the appraisal variables of anxiety and success. The $t$-test results showed significant effects with a medium effect size for anxiety $[t(39)=2.44, p<.015$, 
Cohen's $\mathrm{d}=.38]$ and success $[t(39)=-3.20, p<.015$ Cohen's $\mathrm{d}=.50]$ between Task 1 and Task 3. The difference between Task 2 and 3 was not significant when the Bonferroni correction was applied. No significant difference was found between Tasks 1 and 2 (see Table 2). These results indicate that the related picture narration task was perceived to be considerably less anxiety provoking and led to higher evaluations of success than the unrelated picture narration story task. The participants demonstrated similar affective appraisals of the tasks in terms their motivational value and interest.

\section{Insert Table 2 here}

In order to answer our second and third research questions, concerning how learners' affective appraisals of tasks related to utterance fluency and the perceived fluency of raters, respectively, correlations were computed across tasks (see Table 3). For Task 1, the analyses showed a strong positive correlation between participants' appraisals of success and both their articulation rate and their average pause time (see Table 3). Appraisals of success were also positively correlated with experts' rating of participants' fluency on Task 1 . There was also a strong positive correlation between appraisals of motivation and articulation rate. Thus, when participants' appraisals of success and motivation on tasks were high, they had a better articulation rate and average pause time during task performance.

\section{Insert Table 3 here}

For Task 2 moderate negative correlations were found between interest and average pause time (see Table 4), and both interest and task motivation were moderately correlated with experts' ratings of participants' fluency. For Task 3, however, the only significant correlation was between success and average pause time.

\section{Insert Tables 4 and 5 here}

As proficiency might have moderated the relationship between affective response and utterance fluency, we carried out the same correlational analyses and partialled out the participants' placement test score. The results were the same (see Tables 6-8), indicating that the relationship between participants' affective appraisals of tasks and the fluency of their performance was not moderated by proficiency.

\section{Insert Tables 6 and 8 here}

\section{Qualitative analysis}

In total, 135 comments referring to students' perceptions of the tasks were collected. We presented the findings relating to task features that characterized the difficulty of tasks in an earlier study (see Préfontaine \& Kormos, 2015). In order to complement the findings of the quantitative phase of the study, the qualitative analysis will focus on illustrative comments that are related to anxiety and perceived success in task performance.

In terms of anxiety, the unrelated picture narration (Task 1) had the highest mean for anxiety (3.30), followed by the story retell (Task 2) (3.23), and the related picture narration (Task 3) (2.90). As can be seen in the qualitative comments below, appraisals of anxiety were frequently related to how difficult or easy the participants judged the task to be:

"Task 2 was the most difficult. It was harder because I felt more constricted about what I was supposed to say, and I did use some artistic license in the end. There was a ton of words that I didn't know and because of this I circled a little bit higher on the 
nervous level; this task made me more uneasy because I didn't have the freedom to use whatever words I wanted." (Participant 30)

“Task 3 was easier. I wasn't as nervous as I was for Task 1 and I think I did better. I didn't really plan anything. Once I had gone through the sequence and found the end, I knew where I was going." (Participant 10)

From these excerpts, we can observe the influence of task demands on perceptions of anxiety. Participants tended to report high anxiety when they lacked the linguistic resources to express the set task content, and they were not allowed to maneuver around linguistic difficulties. It is thus important that teachers are aware of the fact that tasks that push learners to exploit their available linguistic repertoire with little flexibility to tailor content to their resources can be particularly anxiety provoking.

In terms of appraisals of success, the story retell task (Task 2) provoked the lowest mean for appraisals of success (3.65), followed by the unrelated picture narration task (Task 1) (3.58), and the related picture narration description task (Task 3) (4.10), which prompted the highest appraisals of success. During the interview a student commented on Task 3 :

"I felt like I did better on this one. I spoke longer, there was more to talk about and this task had the degree of openness that I like - there was more to describe in this one". (Participant 17)

By contrast, another student appraised the characteristics of Task 2 as contributing to overall ease in fluent speech production:

"The horse task was easier because I didn't have to make up a story, I just had to report."

(Participant 29)

Our analysis also suggests that 'freedom of expression' seems to contribute to perceptions of success.

"Task 1 was the easiest because I could make it as simple or as complex as I wanted.

The more freedom I have with things the easier it is for me." (Participant 31)

Therefore, these appraisals of success, illustrate both students' impressions of what constitutes success of task performance and how success can be achieved. According to their spontaneous responses, tasks that have a set storyline and provide opportunities for detailed description and freedom of expression appear to be features that promote feelings of success in L2 speech performance for this particular group of French learners.

Although narrative tasks are used extensively in L2 teaching contexts, research studies that actually report on student perceptions of such tasks are rare. The comments collected on the three tasks employed in the current study fill this gap in the often neglected but critical aspect of learner-centered teaching pedagogy. It is hoped that this aspect of our study will prompt teachers to ask for students' perceptions regarding the tasks used to assess their L2 speech abilities.

\section{Discussion and Conclusions}

Our first research question sought to examine how L2 French speakers' affective appraisals differed across three monologic narrative speech tasks that varied in the cognitive demands they placed on the conceptualization and formulation phase of speech production. The quantitative analysis indicated that the unrelated picture narration task (Task 1) and related 
picture narration task (Task 3) differed significantly with regard to appraisals of anxiety and success, but no significant differences were found between the unrelated picture narration task (Task 1) and the story retell task (Task 2). In the retrospective interview data, participants also stated that the cognitive demands and design features of Tasks 1 and 2 provoked more anxiety and put pressure on their attentional, cognitive and affective processing. Participants also told us that their perceptions of anxiety were related to a lack of task structure and a concomitant need for content planning. Perceptions of success were associated with freedom of expressivity, creativity and overall task malleability to allow them to customize their speech production given their linguistic resources. Based on our quantitative results and the illustrative qualitative comments, we suggest that teachers need to consider that high creativity demands of narration might provoke feelings of anxiety and low perceptions of successful task performance among some learners. In order to gain a better understanding of task features that promote feelings of success and anxiety, language practitioners could also apply a similar retrospective approach with their students to the one used in our research. Teachers could then compare the learners' appraisals with their actual speech performance, and make adjustments in tasks and task choices to cater for the differing needs and preferences of their students.

Our findings also reveal that the need to render content precisely, without room to maneuver around learners' gap of lexical or syntactic knowledge, can prompt feelings of anxiety. This affective response, however, does not seem to have a detrimental effect on performance, which is shown in the lack of significant correlations between anxiety and fluency in Task 2. Therefore, even though a task design feature that requires accurate and precise expression of content and ideas might contribute to appraisals of anxiety, it should not be discarded in instructional design. If the input text is in the students' L1, like in our research, they can be encouraged to look up relevant words and phrases in dictionaries. Even if students do not share the same L1 background, an input text chosen by the students in their L1 on a topic that they find interesting and motivating can still serve as useful tool for enhancing fluency. L1 input texts offer opportunities for translanguaging and allow L2 users to draw on their multilingual resources (Garcia, 2009). If the input text is provided to learners in their L2, teachers can add glossaries of unfamiliar words, which might also alleviate students' feelings of anxiety and promote language development on these types of tasks.

Our second research question sought to establish whether learners' affective appraisals of speech tasks were related to utterance fluency. In the task where learners had to narrate given content depicted by a series of pictures, affective responses played a relatively minor role in influencing the fluency of performance. This task was appraised to be the least anxiety provoking and participants felt they performed successfully in it. However, findings varied considerably across tasks indicating that teachers might best provide a variety of tasks as they are likely to influence L2 fluency, and subsequently speech perception, differently. However, real-life language use rarely caters to what learners can master today. To make progress in their language development, learners need to be challenged, provided with scaffolding and encouraged on their performance in order to continue to take risks. It is thus advised that L2 teaching focus on placing learners in the zone of proximal development (Vygotsky, 1962).

Finally, our third research question asked how learners' affective appraisals of speech tasks are related to the perceptions of raters. Interestingly, ratings of perceived fluency were highly related to appraisals of success, indicating that students' perception of their own performance was in line with those of the raters (for a discussion of the relationship between utterance and perceived fluency measures in this dataset see Préfontaine, et al., 2015).

Taken together, these results indicate that the cognitive demands of tasks have an impact on learners' responses and performance. The unrelated picture narrative (Task 1), which can be argued to have placed high conceptualization demands on learners had an influential impact on participants' perceptions of success and may have impacted both the 
objective and subjective measures of performance. In similar types of tasks, visual or textual input that determine the setting, events or characters in a narrative, need to be chosen so that they are motivating for learners. Although it is unlikely that such input can be designed in a way to be motivating and engaging for all the learners even within a relatively homogenous group, being familiar with the students' interests can ensure that a high proportion of learners would be motivated in performing the task.

The results for Task 2, in which students were asked to retell a horse-back riding accident that they initially read in their first language indicate a negative relationship between interest and native speaker ratings of fluency. This finding might indicate that native speakers are attuned to voice expressivity and intonation as a key characteristic in L2 French speech perception that displays one's interest in a given task (see Préfontaine \& Kormos, 2016). A similar inverse relationship can be seen between motivation and fluency scores awarded by the native speaker judges. Participants' interest in this task and motivation to complete it might have been triggered by the topic or the story-retell aspect of the task design. We can hypothesize that perhaps those participants who found the topic and task interesting and motivating invested more effort in encoding the content of the task more precisely and selecting the most accurate and appropriate lexis to express this content. The increased attention to content planning and lexical selection might then have negatively affected fluency. This suggests that decrease in fluency might not necessarily indicate inefficiencies of the speech production process (cf. Lennon, 1990), but in certain tasks it can be a signal of engagement and interest. Therefore, it is important that language teachers recognize that some learners might become involved in a task to the extent that it slows their speech production processes down. Awareness of the effect of interest and motivation on speech production is needed when learners' performance is assessed or if teachers give evaluative feedback.

Our study has a number of limitations, the most important of which is that we only used three types of tasks and they all required participants to produce a monologue. Future research with a wider variety of tasks that differ in other design features and that involve interaction between interlocutors would be needed to gain a more nuanced insight into the complex interrelationships between task characteristics, affective factors and learner performance. Further research that investigates other linguistic and discourse features of the participants' input would also be necessary. Our participants were L2 French speakers in a Canadian context and future studies would have to ascertain the applicability of our findings to other multilingual language use and learning contexts. Another limitation of our study is that we only used a very brief questionnaire with single items tapping into participants' affective reactions to learning tasks. The field would benefit from additional research that applies multi-item scales that assess task motivation before and after task performance (e.g. Boekaerts, 2002). Qualitative case studies that examine individual variation in affective reactions and their dynamic interplay with task characteristics and performance would also be welcome.

In spite of these limitations, our mixed-methods study brings together both quantitative and qualitative approaches to address task-related research and pedagogical problems by investigating the role of affect in fluent speech production and perception. Although no previous empirical research on affect and L2 French speech tasks has been conducted, thus leaving no comparisons upon which to draw more conclusions, this study provides the basis of a framework for understanding the role that affective factors play in L2 speech processing and how consideration for learners' task perceptions inform fluent performance. The quantitative and qualitative results support the idea that task-related affective factors impact both utterance and perceived fluency and highlight the fact that learners can elucidate justifications relevant to their affective appraisals of pedagogical tasks. 


\section{References}

Boekaerts, M. (2002). The on-line motivation questionnaire: A self-report instrument to assess students' context sensitivity. In P. R. Pintrich \& M. L. Maehr (Eds.), Advances in motivation and achievement (Vol. 12. New directions in measures and methods, pp. 77-120). Amsterdam, Netherlands: JAI.

Boersma, P., \& Weenink, D. (2010). Praat: doing phonetics by computer (Version 5.0.25) [Computer software].

Bosker, H., Pinget, A., Quené, H., Sanders, T., \& De Jong, N. (2013). What makes speech sound fluent? The contributions of pauses, speed and repairs. Language Testing, 30, $159-175$.

Cohen, J. W. (1988). Statistical power analysis for the behavioral sciences (2 ed.). Hillsdale, NJ: Lawrence Erlbaum Associates.

Council of Europe. (2001). Common European Framework of reference of languages: Learning, teaching, assessment. Cambridge: Cambridge University Press.

De Jong, N. H., Steinel, M. P., Florijn, A., Schoonen, R., \& Hulstijn, J. (2012). The effect of task complexity on functional adequacy, fluency and lexical diversity in speaking performances of native and non-native speakers. In A. Housen, F. Kuiken, \& I. Vedder (Eds.), Dimensions of L2 Performance and Proficiency: Complexity, Accuracy and Fluency in SLA (pp. 121-142). Philadelphia/Amsterdam: John Benjamins.

De Jong, N. H., \& Wempe, T. (2009). Praat script to detect syllable nuclei and measure speech rate automatically. Behavior Research Methods, 41, 385-390.

Dörnyei, Z. (2002). The motivational basis of language learning tasks. In P. Robinson (Ed.), Individual differences and instructed language learning (pp. 137-158). Amsterdam: John Benjamins.

Dörnyei, Z., \& Kormos, J. (2000). The role of individual and social variables in oral task performance. Language Teaching Research, 4, 275-300.

Dörnyei, Z., \& Kormos, J. (2004). The interaction of linguistic and motivational variables in second language task performance. Zeitschrift für Interkulturellen

Fremdsprachenunterricht [online], 9, 1-19. Retrieved from https://zif.spz.tudarmstadt.de/jg-09-2/beitrag/kormos2.htm

Dörnyei, Z., \& Ryan, S. (2015). The psychology of the language learner revisited: Routledge.

Ejzenberg, R. (2000). The juggling act of oral fluency: A psycho-sociolinguistic metaphor. In H. Riggenbach (Ed.), Perspectives on Fluency (pp. 287-313). Ann Arbor: University of Michigan Press.

Ericsson, K. A., \& Simon, H. A. (1980). Verbal reports as data. Psychological Review, 87, $215-251$.

Ericsson, K. A., \& Simon, H. A. (1993). Protocol analysis: Verbal reports as data (Rev. ed.). Cambridge: MIT Press.

Freed, B. (2000). Is fluency, like beauty, in the eyes (and ears) of the beholder? In H. Riggenbach (Ed.), Perspectives on fluency (pp. pp.243-265): Ann Arbor: University of Michigan Press.

Freed, B., Segalowitz, N., \& Dewey, D. (2004). Context of learning and second language fluency in French: Comparing regular classroom, study abroad, and intensive domestic immersion programs. 26, 275-301.

Garcia, O. (2009). Bilingual education in the 21st century: A global perspective. Malden, MA: Wiley-Blackwell. 
Gilabert, R. (2007). Effects of manipulating task complexity on self-repairs during L2 oral production. International Review of Applied Linguistics in Language Teaching, 45, 215-240.

Harackiewicz, J. M., Durik, A. M., Barron, K. E., Linnenbrink, E. A., \& Tauer, J. M. (2008). The role of achievement goals in the development of interest: Reciprocal relations between achievement goals, interest, and performance. Journal of Educational Psychology, 100, 105-122.

Hidi, S., \& Renninger, K. (2006). The four-phase model of interest development. Educational Psychologist, 41, 111-127.

Hidi, S., Renninger, K. A., \& Krapp, A. (1992). The present state of interest research. In S. Hidi, K. A. Renninger, \& A. Krapp (Eds.), The role of interest in learning and development (pp. 433-446). Hillsdale, NJ: Lawrence Erlbaum Associates.

Horwitz, E. K., Horwitz, M. B., \& Cope, J. (1986). Foreign language classroom anxiety. The Modern Language Journal, 70, 125-132.

Jackson, D. O., \& Suethanapornkul, S. (2013). The Cognition Hypothesis: A synthesis and meta-analysis of research on second language task complexity. Language Learning, 63, 330-367.

Jülkunen, K. (1989). Situation and task-specific motivation in foreign language learning. Jeonsu, Finland: University of Joensuu.

Kormos, J. (2000). The role of attention in monitoring second language speech production. Language Learning, 50, 343-384.

Kormos, J. (2011). Speech production and the Cognition Hypothesis. In P. Robinson (Ed.), Second language task complexity: Researching the Cognition Hypothesis of language learning and performance (pp. 39-59). Philadelphia/Amsterdam: John Benjamins.

Kormos, J., \& Dénes, M. (2004). Exploring measures and perceptions of fluency in the speech of second language learners. System, 32, 145-164.

Kormos, J., \& Trebits, A. (2012). The role of task complexity, modality and aptitude in narrative task performance. Language Learning, 439-472.

Lantz, B. (2013). The impact of continuity violation on ANOVA and alternative methods. Journal of Modern Applied Statistical Methods, 12, 105-120.

Lennon, P. (1990). Investigating fluency in EFL: A quantitative approach. Language Learning, 40, 387-417.

Lennon, P. (2000). The lexical element in spoken second language fluency. In H. Riggenbach (Ed.), Perspectives on fluency (pp. 25-42). Ann Arbor, MI: University of Michigan Press.

Levelt, W. J. M. (1989). Speaking: From intention to articulation. Cambridge, MA: MIT Press.

MacIntyre, P. D., \& Gardner, R. C. (1994). The subtle effects of language anxiety on cognitive processing in the second language. Language Learning, 44, 283-305.

Poupore, G. (2013). Task motivation in process: A complex systems perspective. Canadian Modern Language Review, 69, 91-116.

Poupore, G. (2015). The Influence of Content on Adult L2 Learners' Task Motivation: An Interest Theory Perspective. Canadian Journal of Applied Linguistics, 17, 69-90.

Préfontaine, Y. (2013). Fluency in French: A psycholinguistic study of second language speech production and perception. (Unpublished doctoral dissertation), Lancaster University, Lancaster, UK.

Préfontaine, Y., \& Kormos, J. (2015). The Relationship Between Task Difficulty and Second Language Fluency in French: A Mixed Methods Approach. The Modern Language Journal, 99, 96-112. 
Préfontaine, Y., \& Kormos, J. (2016). A qualitative analysis of perceptions of fluency in second language French. International Review of Applied Linguistics, 54, 151-169.

Préfontaine, Y., Kormos, J., \& Johnson, D. (2015). How do utterance measures predict raters' perceptions of fluency in French as a second language? Language Testing, 1-21. Retrieved from doi:10.1177/0265532215579530

Renninger, K., Nieswandt, M., \& Hidi, S. (2015). Interest in mathematics and science learning. Washington, DC: American Educational Research Association.

Riggenbach, H. (1991). Toward an understanding of fluency: A microanalysis of nonnative speaker conversations. Discourse Processes, 14, 423-441.

Robinson, P. (2001). Task complexity, task difficulty, and task production: Exploring interactions in a componential framework. Applied Linguistics, 21, 27-57.

Robinson, P. (2011). Second language task complexity, the Cognition Hypothesis, language learning and performance. In P. Robinson (Ed.), Second language task complexity: Researching the cognition hypothesis of language learning and performance (pp. 338). Philadelphia/Amsterdam: John Benjamins.

Robinson, P., \& Gilabert, R. (2007). Task complexity, the Cognition Hypothesis and second language learning and performance. International Review of Applied Linguistics in Language Teaching, 45, 161-176.

Rubin, H. J., \& Rubin, I. (2005). Qualitative interviewing: The art of hearing data (2nd ed.). Thousand Oaks: Sage.

Révész, A. (2014). Towards a fuller assessment of cognitive models of task-based learning: Investigating task-generated cognitive demands and processes. Applied Linguistics.

Seegers, G., \& Boekaerts, M. (1993). Task motivation and mathematics achievement in actual task situations. Learning and Instruction, 3, 133-150.

Segalowitz, N. (2010). Cognitive bases of second language fluency. New York: Routledge.

Spielberger, C. D. (1983). Manual for the state-trait anxiety inventory. Palo Alto, CA: Consulting Psychologists Press.

Tavakoli, P., \& Foster, P. (2011). Task design and second language performance: The effect of narrative type on learner output. Language Learning, 61, 37-72.

Tavakoli, P., \& Skehan, P. (2005). Strategic planning, task structure and performance testing. In R. Ellis (Ed.), Planning and task performance in a second language (pp. 239-273). Philadelphia/Amsterdam: John Benjamins.

Towell, R., Hawkins, R., \& Bazergui, N. (1996). The development of fluency in advanced learners of French. Applied Linguistics, 17, 84-119.

Vygotsky, L. S. (1962). Thought and Language. Cambridge, MA: MIT Press. 


\begin{tabular}{lccc}
\hline \multirow{2}{*}{$\begin{array}{c}\text { Appraisal } \\
\text { Variable }\end{array}$} & Task 1 & Task 2 & Task 3 \\
\cline { 2 - 4 } & $M(S D)$ & $M(S D)$ & $M(S D)$ \\
\hline Anxiety & $3.30(1.20)$ & $3.23(1.09)$ & $2.90(0.93)$ \\
Success & $3.58(0.87)$ & $3.65(1.03)$ & $4.10(1.08)$ \\
Interest & $4.78(0.80)$ & $4.93(0.80)$ & $4.82(0.71)$ \\
Motivation & $4.35(1.00)$ & $4.63(0.90)$ & $4.53(0.82)$
\end{tabular}

Table 1 Descriptive Statistics for the Task Appraisal Questionnaire (n=40) 


\begin{tabular}{|c|c|c|c|c|c|c|c|}
\hline & \multirow[t]{2}{*}{ Mean } & \multirow[t]{2}{*}{ SD } & \multicolumn{2}{|c|}{$95 \%$ CI of difference } & \multirow[t]{2}{*}{$\mathrm{t}$} & \multirow[t]{2}{*}{$\mathrm{p}$} & \multirow[t]{2}{*}{$\mathrm{F}$} \\
\hline & & & Lower & Upper & & & \\
\hline Success T1-T2 & -.07 & 1.11 & -.43 & .28 & -.42 & .674 & \\
\hline Success T2-T3 & -.45 & 1.35 & -.88 & -.01 & -2.09 & .043 & 5.0 \\
\hline Success T1-T3 & -.52 & 1.03 & -.85 & -.19 & -3.20 & .003 & \\
\hline Anxiety T1-T2 & .07 & 1.20 & -.311 & .461 & .39 & .696 & \\
\hline Anxiety T2-T3 & .36 & 1.05 & -.018 & .668 & 1.98 & .042 & 3.5 \\
\hline Anxiety T1-T3 & .40 & 1.03 & .070 & .730 & 2.44 & .019 & \\
\hline Interest $\mathrm{T} 1-\mathrm{T} 2$ & -.12 & 1.18 & -.50 & .25 & -.67 & .507 & \\
\hline Interest $\mathrm{T} 2-\mathrm{T} 3$ & .07 & .94 & -.22 & .37 & .50 & .618 & .2 \\
\hline Interest $\mathrm{T} 1-\mathrm{T} 3$ & -.05 & .81 & -.31 & .21 & -.38 & .700 & \\
\hline Motivation T1-T2 & -.25 & 1.27 & -.65 & .15 & -1.23 & .223 & \\
\hline Motivation T2-T3 & .07 & 1.04 & -.26 & .41 & .45 & .653 & .9 \\
\hline Motivation T1-T3 & -.17 & .90 & -.46 & .11 & -1.22 & .227 & \\
\hline
\end{tabular}

* Indicates $p<.05$.

Table 2 Differences in One-way Repeated-Measures ANOVAs and Paired-Samples t-tests for Task Appraisals 


\begin{tabular}{lllll}
\hline & $\begin{array}{l}\text { Articulation } \\
\text { rate }\end{array}$ & $\begin{array}{l}\text { Pause } \\
\text { Frequency }\end{array}$ & $\begin{array}{l}\text { Average } \\
\text { Pause } \\
\text { Time }\end{array}$ & Rating \\
\hline Anxiety & -.033 & -.112 & -.043 & -.137 \\
Success & $.412^{* *}$ & -.306 & $.443^{* *}$ & $.469^{* *}$ \\
Interest & .238 & -.105 & .162 & .196 \\
Motivation & $.410^{* *}$ & -.027 & $.313^{*}$ & .192 \\
* Indicates $p<0.05$. & & & \\
** Indicates $p<0.01$. & & &
\end{tabular}

Table 3 Correlations between utterance and perceived fluency measures in Task 1 


\begin{tabular}{lllll}
\hline & $\begin{array}{l}\text { Articulation } \\
\text { rate }\end{array}$ & $\begin{array}{l}\text { Pause } \\
\text { Frequency }\end{array}$ & $\begin{array}{l}\text { Average } \\
\text { Pause } \\
\text { Time }\end{array}$ & Rating \\
\hline Anxiety & .222 & -.025 & .183 & .185 \\
Success & .105 & -.073 & .102 & .116 \\
Interest & -.287 & .137 & -.300 & $-.347^{*}$ \\
Motivation & -.164 & .167 & -.201 & $-.377^{*}$ \\
\hline
\end{tabular}

Table 4 Correlations between utterance and perceived fluency measures in Task 2 


\begin{tabular}{lllll}
\hline & $\begin{array}{l}\text { Articulation } \\
\text { rate }\end{array}$ & $\begin{array}{l}\text { Pause } \\
\text { Frequency }\end{array}$ & $\begin{array}{l}\text { Average } \\
\text { Pause } \\
\text { Time }\end{array}$ & Rating \\
\hline Anxiety & -.211 & .247 & -.311 & -.218 \\
Success & .262 & -.279 & $.354^{*}$ & .126 \\
Interest & .190 & -.136 & .165 & .147 \\
Motivation & .233 & -.076 & .216 & .108 \\
\hline
\end{tabular}

Table 5 Correlations between utterance and perceived fluency measures in Task 3 


\begin{tabular}{|c|c|c|c|}
\hline & $\begin{array}{l}\text { Articulation } \\
\text { rate }\end{array}$ & $\begin{array}{l}\text { Pause } \\
\text { Frequency }\end{array}$ & $\begin{array}{l}\text { Average } \\
\text { Pause } \\
\text { Time }\end{array}$ \\
\hline Anxiety & -.071 & -.091 & -.077 \\
\hline Success & $.375 *$ & -.254 & $.387 *$ \\
\hline Interest & .329 & -.162 & .251 \\
\hline Motivation & $.425 * *$ & .023 & .299 \\
\hline
\end{tabular}

Table 6. Correlations between utterance and perceived fluency measures in Task 1 with placement test score as a co-variant 


\begin{tabular}{|c|c|c|c|}
\hline & $\begin{array}{l}\text { Articulation } \\
\text { rate }\end{array}$ & $\begin{array}{l}\text { Pause } \\
\text { Frequency }\end{array}$ & $\begin{array}{l}\text { Average } \\
\text { Pause } \\
\text { Time }\end{array}$ \\
\hline Anxiety & .247 & -.055 & .202 \\
\hline Success & .112 & -.089 & .126 \\
\hline Interest & -.307 & .094 & -.277 \\
\hline Motivation & -.126 & .119 & -.128 \\
\hline
\end{tabular}

Table 7. Correlations between utterance and perceived fluency measures in Task 2 with placement test score as a co-variant 


\begin{tabular}{lrrr}
\hline & $\begin{array}{l}\text { Articulation } \\
\text { rate }\end{array}$ & $\begin{array}{l}\text { Pause } \\
\text { Frequency }\end{array}$ & $\begin{array}{l}\text { Average } \\
\text { Pause } \\
\text { Time }\end{array}$ \\
\hline Anxiety & -.196 & .243 & -.307 \\
Success & .266 & -.253 & $.352^{*}$ \\
Interest & .245 & -.157 & .218 \\
Motivation & .278 & -.101 & .269 \\
\hline Indicates $p<0.05$. & & &
\end{tabular}

Table 8. Correlations between utterance and perceived fluency measures in Task 3 with placement test score as a co-variant 


\section{Appendices}

Appendix 1: L2 Fluency Assessment Grid

Please indicate the participant's general assessment of L2 fluency in French by placing an ' $\mathrm{X}$ ' next to the descriptor. We are interested in your personal opinion. Thank you very much for your help.

\begin{tabular}{|l|l|l|}
\hline & $\begin{array}{l}\text { The participant can express themselves spontaneously at length } \\
\text { with a natural colloquial flow, avoiding or backtracking around any } \\
\text { difficulty so smoothly that the interlocutor is hardly aware of it. }\end{array}$ & $\begin{array}{l}\text { Highest } \\
\text { level or } \\
\text { CEF C2 }\end{array}$ \\
\hline $\begin{array}{l}\text { The participant can express themselves fluently and spontaneously, } \\
\text { almost effortlessly. Only a conceptually difficult subject can hinder } \\
\text { a natural, smooth flow of language. }\end{array}$ & CEF C1 \\
\hline $\begin{array}{l}\text { The participant can produce stretches of language with fairly even } \\
\text { tempo, although they can be hesitant as search for patterns and } \\
\text { expressions. There are few noticeably long pauses. }\end{array}$ & CEF B2 \\
\hline $\begin{array}{l}\text { The participant can keep going comprehensibly, even though } \\
\text { pausing for grammatical and lexical planning and repair is very } \\
\text { evident, especially in longer stretches of free production. }\end{array}$ & CEF B1 \\
\hline $\begin{array}{l}\text { The participant can make themselves understood in very short } \\
\text { utterances, even though pauses, false starts and reformulation are } \\
\text { very evident. }\end{array}$ & $\begin{array}{l}\text { CEF A2 } \\
\text { The participant can manage very short isolated utterances, with } \\
\text { much pausing to search for expressions, to articulate less familiar } \\
\text { words, and to repair communication. }\end{array}$ & $\begin{array}{l}\text { Lowest } \\
\text { level or } \\
\text { CEF A1 }\end{array}$ \\
\hline
\end{tabular}

Source: Common European Framework, 2001, Table 3, pp. 28-29 


\section{Appendix 2: Task Appraisal Questionnaire}

Please circle one of the numbers as appropriate about the speaking task that you have just narrated. This is not a test so there are no "right" or "wrong" answers. We are interested in your personal opinion. Thank you very much for your help.

1. How nervous were you to do this task?

\begin{tabular}{|c|c|c|c|c|c|}
\hline 1 & 2 & 3 & 4 & 5 & 6 \\
\hline $\begin{array}{c}\text { Very } \\
\text { relaxed }\end{array}$ & Relaxed & $\begin{array}{c}\text { Moderately } \\
\text { relaxed }\end{array}$ & $\begin{array}{c}\text { Moderately } \\
\text { nervous }\end{array}$ & Nervous & $\begin{array}{c}\text { Very } \\
\text { nervous }\end{array}$ \\
\hline
\end{tabular}

2. How well do you think you did this task?

\begin{tabular}{|c|c|c|c|c|c|}
\hline 1 & 2 & 3 & 4 & 5 & 6 \\
\hline $\begin{array}{c}\text { Didn't do } \\
\text { well at all }\end{array}$ & $\begin{array}{c}\text { Didn't do } \\
\text { well }\end{array}$ & $\begin{array}{c}\text { Moderately } \\
\text { poor }\end{array}$ & $\begin{array}{c}\text { Moderately } \\
\text { well }\end{array}$ & Well & Very well \\
\hline
\end{tabular}

3. How interesting did you think this task was?

\begin{tabular}{|c|c|c|c|c|c|}
\hline 1 & 2 & 3 & 4 & 5 & 6 \\
\hline Not at all & Not & Moderately & Moderately & Interesting & Very \\
interesting & interesting & $\begin{array}{c}\text { not } \\
\text { interesting }\end{array}$ & interesting & & interesting \\
& & & &
\end{tabular}

4. Would you like to do more tasks like this?

\begin{tabular}{|c|c|c|c|c|c|}
\hline 1 & 2 & 3 & 4 & 5 & 6 \\
\hline Not at all & No & $\begin{array}{c}\text { Moderately } \\
\text { no }\end{array}$ & $\begin{array}{c}\text { Moderately } \\
\text { yes }\end{array}$ & Yes & Very much \\
& & yes
\end{tabular}

